\title{
ОПТИМИЗАЦИЯ МОДЕЛИ ГЛОБАЛЬНОГО БИОГЕОХИМИЧЕСКОГО ЦИКЛА УГЛЕРОДА
}

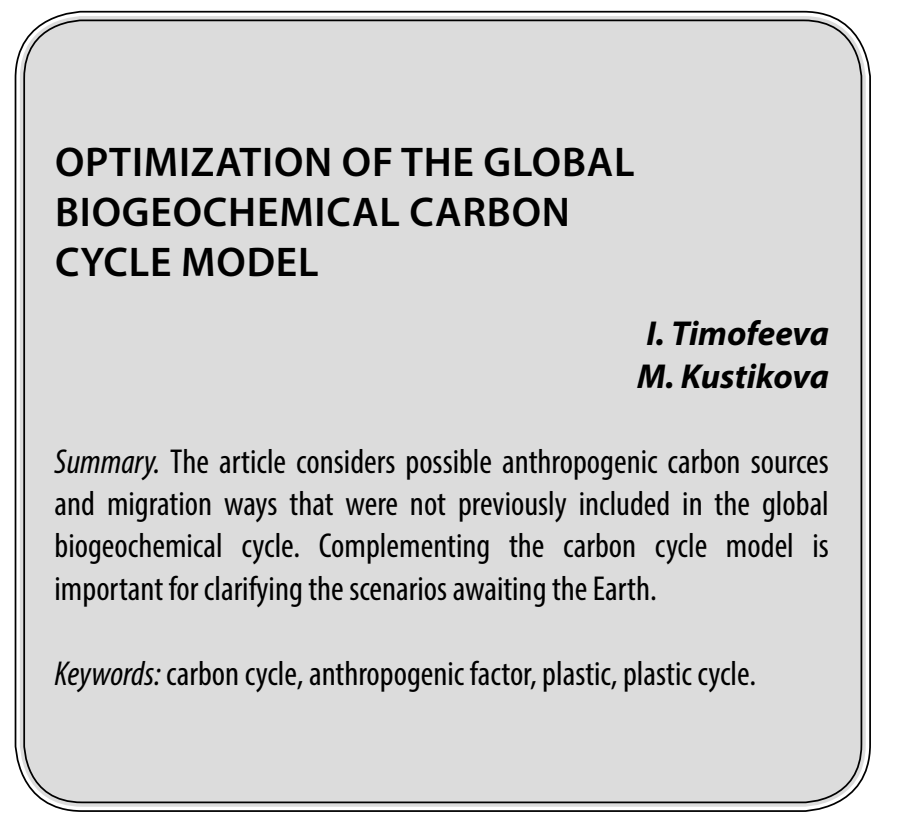

\section{Введение}

B се органические соединения включают углерод в свой состав, поэтому с уверенностью можно сказать «Жизнь на Земле основана на углероде». Атомы углерода постоянно мигрируют в биосфере, а глобальный биогеохимический цикл углерода является жизнеобеспечивающим.

Основные запасы углерода на Земле представлены диоксидом углерода и находятся в газообразном и в растворенном виде в Мировом океане. Однако при формировании сбалансированной схемы потоков оказывается, что примерно 27\% стока углерода из атмосферы остаются неопределенными. При этом замкнутость, например, круговорота углерода по стокам и источникам составила 80-85\%. [2] Это означает, что неопределенность сбалансированности глобального цикла углерода составляет $15-20 \%$.

В трудах академика В.И. Вернадского сформулировано представление о человечестве как о глобальной геологической силе. Он полагал, что антропогенное усиление миграции веществ в биосфере является закономерным процессом и находится в полном соответствии с установленными биогеохимическими принципами. [3] В исследованиях А.А. Баренбаума, К.Я. Кондратьева и В.Ф.Крапивина указано на необходимость уточне-
Тимофеева Ирина Валерьевна Преподаватель, ФГФОУВО «Национальный исследовательский университет ИТМО»

ivtimofeeva@itmo.ru

Кустикова Марина Александровна К.т.н., дочент, ФГАОУ ВО «Начиональный исследовательский университет ИТМО» marinakustikova@mail.ru

Аннотация. В статье рассмотрены возможные антропогенные источники углерода и пути их миграции ранее не включенные в глобальный биогеохимический цикл. Дополнение модели цикла углерода важно для уточнения сценариев ожидающих Землю.

Ключевые слова: круговорот углерода, антропогенный фактор, пластик, круговорот пластика.

ния биогеохимической модели круговорота углерода в окружающей среде. [1, 2, 6-8]

C середины XX века было произведено более 8,3 миллиарда тонн пластиков, которые разрушаясь превращаются в микро- и наночастицы, что может стать одним из резервуаров углерода на планете. Глобальный биогеохимический цикл углерода является объектом исследования в международных и национальных научных программах и определяется как жизнеобеспечивающий.

В современных сбалансированных моделях цикла углерода учитываются антропогенные выбросы углеродсодержащих веществ, однако остаются без внимания поступления в компоненты окружающей среды пластиков. Реализуемая в рамках глобального углеродного проекта GCP (Global Carbon Project) программа контроля потоков углерода в условиях развития современной цивилизации учитывает антропогенную эмиссию $\mathrm{CO}^{2}$ и эквивалентов, но пренебрегает углеродом, содержащимся в пластиках, основой производства которых является нефть. [8] Доля стока углерода в имеющихся моделях остается необъяснимой, что в значительной мере снижает доверие к существующим сценариям ожидающих Землю.

Актуализация модели круговорота углерода с учетом пластиковых полимеров позволит повысить точность 


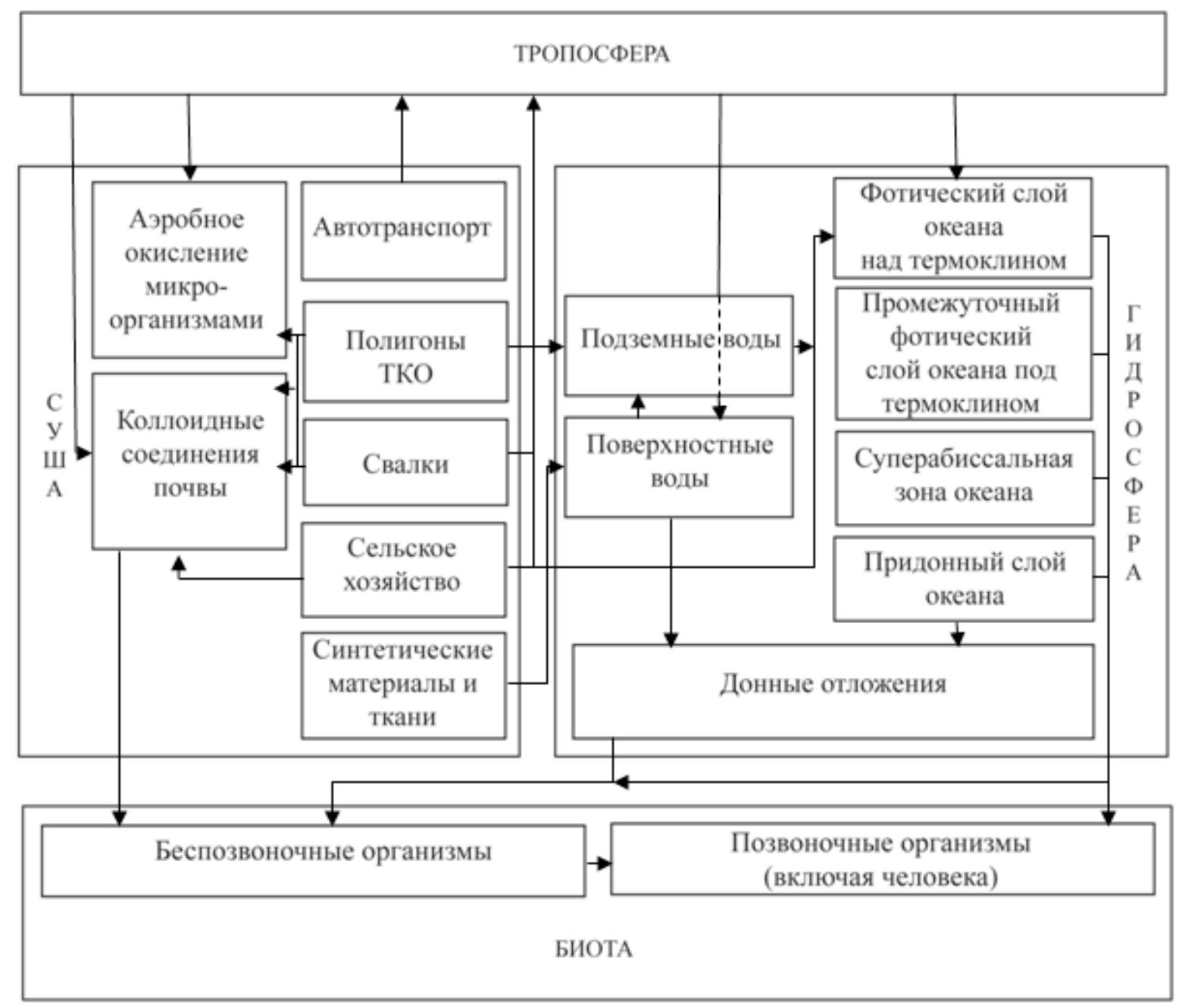

Рис. 1. Глобальный цикл пластиковых углеводородов в системе атмосфера-гидросфера-суша-биота.

прогнозов протекания биогеохимических процессов на планете.

\section{Основная часть}

Описание антропогенных модификаций всех биогеохимических циклов осуществляется по одной схеме. Первично количественно оцениваются формы антропогенной деятельности, которые способны активировать миграцию соединений ключевого элемента цикла, в данном случае - углерода, а также описываются изменения некоторых резервуаров и стоков. Следующим шагом является построение балансовой схемы, основными связями которой являются входящие и исходящие потоки элемента в модели суша-атмосфера-океан.

Большое внимание в настоящие время уделяется расчетам антропогенной эмиссии $\mathrm{CO}^{2}$ и эквивалентов. Однако поступление пластиковых частиц в атмосферу, почву и океан может представлять серьезную проблему для биосферы, а также оказать неблагоприятное воздействие на экономические процессы. [4]

Объемы производства пластика увеличиваются пропорционально добыче нефти и сокращения его производства не предвидится. Из общего количества 8,3 млрд. т, более половины было произведено за последние 10 лет. Основные оценочные данные по влиянию микро- и нанопластиков на компоненты окружающей среды приведены в многочисленных статьях и объединены в отчет группы экспертов GESAMP Международной морской организации (IMO). [15, 5, 13]

Накопленные данные и количественные характеристики позволяют провести анализ и дополнить базовую модель. Между атмосферой, педосферой и гидросферой происходит постоянный интенсивный обмен углеродом, носящий самоорганизующийся характер. Согласно 
принципу Ле Шателье, содержание подвижного углерода в системе стремится к устойчивому соотношению между отношением общего количества подвижного углерода в резервуаре к среднему времени пребывания в системе с константой, характеризующей скорость круговорота углерода. Если условие выполняется, то выход углерода из резервуара системы компенсируется его поступлением из других резервуаров. Если условие не выполняется, то в системе возникают нескомпенсированные перетоки.

Для расчета всех потоков углерода необходимо учитывать пространственные и временные характеристики. Современный уровень знаний позволяет решить задачу лишь частично, но благодаря высокоточным методам идентификации веществ в компонентах окружающей среды, модель может уточняться, тем самым позволяя уменьшить интервал неопределенности в прогностических моделях будущего Земли.

Среди всех факторов, влияющих на перераспределение углерода на планете, наиболее важную роль отводят переносу углерода метеогенными водами и хозяйственной деятельности человека. Благодаря первому фактору избыточный углерод на континентах поступает с метеогенными водами под земную поверхность. [2]

Образование крупных осадочных бассейнов происходит чаще в разломах земной коры. Наличие разломов, с одной стороны, облегчает проникновение метеогенных вод под поверхность Земли, а с другой способствует разгрузке этих вод от транспортируемого ими углерода. [1] Данный факт свидетельствует о том, что круговорот углерода нельзя изучать изолированно от круговорота воды.

С учетом высказанных выше предположений, для оптимизации потоков углерода и снижения неопределенности сбалансированности глобального цикла за основу может быть взята общая схема круговорота углерода [4]

\section{Базовая молель}

Схема глобального цикла пластиковых углеводородов в системе атмосфера-гидросфера-суша-биота (рис. 1) отражает обмены углеродом на границах атмосферы с земными покровами, акваториями и биотой.

Потоки пластиковых углеводородов $C i$ являются функциями температуры, географических координат и других характеристик окружающей среды.

Основными источниками пластика в окружающей среде являются потребительские товары с коротким сроком службы, синтетические ткани, агрокультурная мульчирующая пленка, шлам, резиновая крошка от стирания автомобильных шин.

Микрочастицы пластиков, поступающие в атмосферу, могут выступать в качестве ядер конденсации. Конденсация на ядрах с радиусами порядка $10^{-7}-10^{-5} \mathrm{M}$ происходит без существенного перенасыщения. Частицы пластиков представляют собой устойчивые соединения, которые длительное время могут находиться в составе аэрозолей, переноситься воздушными потоками на дальние расстояния, а также с осадками поступать в почву и водные объекты. Также пластиковые частицы из приземного слоя атмосферы могут подвергаться аэробному окислению микроорганизмами.

В почвах частицы размером $10^{-9}-10^{-7}$ м включены в коллоидные системы. Коллоидные примеси из атмосферных осадков представляют собой очень мелкие агрегаты, благодаря большой удельной поверхности они обладают значительной поверхностной энергией и высокой адсорбционной емкостью. Микропластиковые частицы способны адсорбировать на своей поверхности многие загрязняющие вещества, таким образом, аккумулируя их. Данный факт негативно сказывается как на росте и развитии растительности, так и на педофауне. [14, 12] Почвообразование без живых организмов, особенно мезофауны, которая выполняет очень важную функцию по измельчению органической массы и её превращению в гумус, не возможна. В случае сокращения численности дождевых червей, например, почва постепенно разрушится, потеряет гумус, снизится урожайность.

Из почвы микропластик поступает в подземные и поверхностные воды. Маргинальные фильтры в зонах смешения речных и морских вод в устьях рек флоккулируют и коагулируют значительную часть растворенных (коллоидных) и взвешенных веществ. Кроме седиментации и сорбции происходит биоассимиляция и биофильтрация. Благодаря маргинальному фильтру в этой зоне откладывается до 95\% взвешенных и около 40\% коллоидных веществ речного стока, включая микропластик. [11] В океанах пластики концентрируются в фотическом слое над термоклинном, постепенно деградируют и, мигрируя через глубокие слои, достигает придонного слоя, накапливаясь в донных отложениях.

Микрочастицы пластика имеют широкий спектр размерных групп и низкую плотность, в результате чего многие активно питающиеся живые организмы воспринимают их как источник пищи, а организмы с пассивным типом питания, например, фильтраторы, вынуждены поглощать пластик из среды. Поскольку пластик не расщепляется их ферментативной системой, само по себе проглатывание пластика представляет угрозу для них и может вызывать летальный исход. Особое опасение 
вызывает адсорбционная способность пластиков и поступление с частицами в организм высоких доз загрязнителей. В исследованиях также отмечается высокая вероятность ассимиляции и миграции микропластиков по трофическим цепям, включая человека. $[9,10]$

\section{ВывO $\triangle \mathrm{b}$}

В заключение следует отметить, что замыкание потоков углерода в окружающей среде должно учитывать потоки обусловленные миграцией частиц пластиков. Их не всегда можно спрогнозировать, но с помощью модельных экспериментов открывается возможность для дальнейших целенаправленных исследований биогеохимического цикла углерода с учетом влияния поступления пластиковых частиц в атмосферу, почву, океан и биоту. Разработка структуры модели, учитывающий дополнительный антропогенный источник углерода, позволит точнее характеризовать потоки углерода между резервуарами.

\section{ЛИТЕРАТУРА}

1. Баренбаум, А. А. Механизмы самоорганизации при глобальном геохимическом круговороте вещества на Земле // Синергетика. - М.: Мгу. - 2000.№ 3. - C. 275-295.

2. Бурков Д.В., Крапивин В. Ф., Шалаев В.С. Сбалансированная модель глобального биогеохимического круговорота углерода // Лесной вестник.-2012. № 9. - C. 86-94.

3. Вернадский В.И. Научная мысль как планетное явление / А. Л. Яншин.—- М.: Наука. — 1991.

4. Дегерменджи, А.Г., Барцев С. И. Глобальные малоразмерные модели динамики и устойчивости биосферы // Проблемы окружающей среды и природных ресурсов.-2003.—№ 7.- - С. 32-49.

5. Козловский Н.В., Блиновская Я. Ю. Микропластик — макропроблема Мирового океана // Международный журнал прикладных и фундаментальных исследований. - 2015. - № 10-1.-С. 159-162.

6. Кондратьев К.Я., Крапивин В. Ф. Глобальный круговорот углерода и климат // Исследование Земли из космоса. — 2003.— № 1.—C. 3-15.

7. Кондратьев, К. Я. Моделирование глобального круговорота углерода / К. Я. Кондратьев, В. Ф. Крапивин.— М.: Физматлит.—2004.—336 с.

8. Крапивин В.Ф., Шалаев В.С., Бурков Д. В. Моделирование глобальных циклов углерода и метана // Лесной вестник.— 2015.— № 1. — С. 170-178.

9. Саванина Я.В., Барский Е. Л., Фомина И. А., Лобакова Е.С Загрязнение водной среды микропластиком: воздействие на биологические объекты, очистка // ИТНОУ: информационные технологии в науке, образовании и управлении. - 2019.— № 2. - C. 54-57.

10. Browne M.A., Niven S. J., Galloway T. S., Rowland S. J., Thompson, R. C. Microplastic Moves Pollutants and Additives to Worms, Reducing Functions Linked to Health and Biodiversity // Current Biology. - 2013._- V. 23 (23). - P. 2388-2392.

11. Browne M.A., Crump P., Niven S. J. et al. Accumulations of microplastic on shorelines worldwide: sources and sinks // Environ. Sci. Technol. — 2011.— V. 45.P. $9175-9179$.

12. Defu He, Yongming Luo, Shibo Lu Microplastics in soils: Analytical methods, pollution characteristics and ecological risks// TrAC Trends in Analytical Chemistry.2018. - V.109. - P. 163-172.

13. Ivar do Sul J. A., Costa M. F. The present and future of microplastic pollution in the marine environment // Environmental Pollution. - 2014. - V. 185.— P. 352364.

14. Rilling M. C. Microplastic in terrestrial ecosystems and the soil? // Environ. Sci. Technol._2012.— V. 46. — P. 6453-6454.

15. Sources, fate and effects of microplastics in the marine environment: a global assessment. GESAMP (Kershaw, P. J., ed.). (IMO/FAO/UNESCO-IOC/UNIDO/WMO/IAEA/ UN/UNEP/UNDP Joint Group of Experts on the Scientific Aspects of Marine Environmental Protection). Rep. Stud. GESAMP. V. 90. 2015. 96 p. 